Royal Medical and Chirurgical Society, which is quite analogous in its relations to the general constituent body.

Well, these are the conclusions at which I have long since arrived after mature consideration, and to which I should be quite prepared to give effect in the Council of the College. In private circles I have freely acknowledged my convictions; and as the present crisis seems to demand a public statement of them, may I ask you to disseminate them through the medium of 'THE LANCET?

I am, Sir, yours obediently, Frederick Jaunes Gant.

Connaught-square, June 17th, 1885

\section{AURAL EXOSTOSES.}

\section{To the Editor of THE LANCET.}

SIn,-The first case in which Mr. Field removed an aural exostosis with a dentist's drill occurred in 1877. He says he "got the idea of the operation from Dr. Matthewson's paper." This paper was read at the first Otological Congress held in New York in the autumn of 1876, and was afterwards published. My article appeared in THE LANCET of Jan. 22nd, 1876. Mr. Field says of me: "He has not published any cases for our guidance describing the details of the operation." But in the article referred to I mentioned that since 1874 I had used a dentist's drill to remove aural exostoses, and maintained that they arose from a local irritation of the external meatus, dismissing as quite untenable the theory of their gouty origin. I noted that I had observed as many as fourteen cases (exclusive of hospital patients) in one year. The conditions under which they should be operated upon and, what is of equal or more importance, when they should not, are there most definitely stated. Besides this, in my article in "Holmes' System of Surgery" the pathology of these growths is discussed; the method of operating, the difficulties met with, the conditions under which they should be removed, and when not, are all most carefully described. The same may be said of the last edition of my lectures, in which five pages are devoted to the subject. In regard to the International Medical Congress, the words I actually used (and they are reported in the Transactions) were "Another point which also bears out the theory of a local cause to these growths is one which I have constantly observed (and it has been recorded by others). It is that, when enlargements are found in both canals, patients have been much addicted to sea-bathing."

$$
\begin{gathered}
\text { I am, Sir, your obedient servant, } \\
\text { Wondon, June 13th, 1885. } \\
*^{*} \text {. This controversy must now end.-ED. L. }
\end{gathered}
$$

\section{CHLOROFORM $v$. ETHER.} To the Editor of THE LANCET.

SIR,-I confess to a certain feeling of disappointment that my letter on this subject, which appeared in your journal of March 7th, has not produced more expressions of opinion than it has. In THE LANCET only two have appeared, but I have had sent me from the States a reprint of an article in the Boston Medical and Surgical Journal of April 13th, 1882, entitled " Homicides by Chloroform," which in its condemnation of this drug goes further than Messrs. Braine and Buxton. Mr. Braine, after quoting my contention "that in the production of complete anæsthesia there is little or no difference (in danger to life) between chloroform and ether, whilst in the after-effects, especially as regards vomiting, nausea, and depression of spirits, chloroform is much superior to ether," and saying that this is exactly contrary to what he has been endearouring for years to demonstrate, begs to point out to me that whilst ether is a cardiac stimulant, chloroform, on the other hand, is a depressor of the heart's action; that the former never kills by stopping the heart, whilst, on the contrary, the principal cause of death in fatal chloroform cases is the sudden cessation of the heart's action.

Now, is not this too bad? I write a letter in which it is manifest that $I$ take for granted that chloroform kills by depressing the heart's action, and show how this can be remedied, and then am addressed in the du haut en bas fashion of " Mlay I point out," \&c. I may say further that when I first began giving chloroform, now some twent $y$-four years ago, I unconsciously came to the conclusion that the heart is the organ on which it tells first, for I found myself always keeping one hand on the pulse whilst giving chloroform with the other, long before I had formulated the opinion in so many words. Next, he acknowledges that dangerous symptoms occasionally arise during the administration of ether; but when these do occur the respiratory organs are affected, and there is plenty of time for the proper application of remedies, these symptoms being rarely followed by death. Surely this is begging the whole question, to elucidate which my letter was written. Are these symptoms rarely followed by death? Let us see. Mr. Braine asks me to consult the statistics of fatal cases, in which I shall find that the proportion of deaths under the administration of chloroform is about 1 in 4500 , whilst that under ether is only 1 in 20,000 ! Where are these statistics? I challenge them at once as false and absurd. I have seen, I believe, at least 10,000 cases of chloroform administration with only one death, and that in a woman who, as we found afterwards, had been drinking heavily for a fortnight. But I have got some statistics, compiled for the Registrar-General, who has kindly furnished me with them. I asked for a return of the deaths from the various anæsthetics for the past ten years, but was informed that they could not be given separately: however, a return of the deaths from chloroform and ether (1874-83), in which probably are included those from other aniesthetics in England and Wales, was sent.

Before giving this, let us consider how stand matters bearing on these statistics. First of all, population has increased, but not in so great a degree as to affect materially the comparatively small number of deaths from these drugs. Secondly, there are many operations done now, or done in greater number than were done formerly; but, on the other hand, there are many operations done now without anxesthesia which formerly were done nearly always with it-such as for cataract, \&c. I speak of the days before the introduction of cocaine, and without any reference to it whatever. Thirdly, I believe that there is more care bestowed upon the administration of anæsthetics than formerly; and, fourthly, if what the advocates of ether say is true, there is much greater safety in this drug.

From the first three of these considerations we may fairly draw the conclusion that we ought to expect only a slight increase of deaths owing to the increase of population, the other causes balancing each other, but when we add the fourth, we ought to find a great decrease indeed. Mr. Braine says ether is 4444 times as safe as chloroform! Now what are the facts? In 1882, when ether was much used, the deaths of men from chloroform and ether were more than twice as great as in $\mathbf{1 8 7 4}$, when ether was scarcely used at all. In women in $\mathbf{1 8 8 2}$ there were exactly 75 per cent. more deaths than in 1874. In the second half of the decade, in both sexes, the numbers are 150, as against 104 in the first half.

Ought not these facts to make us pause before we assume that there is the much vaunted safety in ether? Is it not the fact that all anæesthetics universally used are equally fatal, for you cannot abolish all the outward manifestations of life, save those of respiration and circulation, without coming perilously near to the extinction of these. By "equally fatal," I mean this: that if one anæsthetic were used exclusively for all cases through a certain period of time, and another anæsthetic were uved exclusively for all cases through another like period of time, the rate of mortality would be the same in each.

I am told by a friend on whom I can rely implicitly that in a ten years' connexion with a large hospital there have been two deaths from anæsthetics, of which one was from chloroform and one from ether. 1 beliere that during the past year, in the United Kingdom the deaths from chloroform and ether have been about equal.

So far I have confined myself to Mr. Braine's letter, inasmuch as the "safety" point is the principal one. As to the other letter, as Mr. Buxton agrees with Mr. Biaine, I need not enter further into this point, nor need I dilate much on the sequelæ point, as Mr. Buxton agrees with me in considering that the after-effects of ether are far worse than those of chloroform. I think few doubt this. When the ether ware came from the West I made an experiment on myself, and in consequence obtained an accurate idea of what I should think must be the prodromata of suicide. Later, when I tried the drug on patients, I found that whilst the symptoms preiiminary to complete anæsthesia were no less 
terrifying than those of chloroform, the symptoms succeeding were far worse and more prolonged. One old gentleman on whom I operated for cataract had a profound melancholy for several months, which he attributed to ether; and I was repeatedly asked by the matron of St. Paul's Eye and Ear Hospital not to give ether, as the patients were so much more sick and ill, and longer in recovery.

Since writing the above I have received from the Registrar-General a return of the deaths from chloroform and ether-practically of chloroform alone-for the ten years 1864-1873. The numbers are: males 106, females 24, total 130. The lowest year was 1866, with 4 males to 1 female; the highest year was 1872, with 19 males to 4 females.

The following is the copy of the Report furnished me by the Registrar-General.

\section{"England and Wales.}

\section{'Deaths from Chloroform and from Ether registered in} England and Wales in each of the years $18^{\circ} 4$ to 1883.

\begin{tabular}{|c|c|c|c|c|c|c|c|c|}
\hline $\begin{array}{l}\text { Year. } \\
1874\end{array}$ & $\cdots$ & $\cdots$ & ... & $\begin{array}{c}\text { Males. } \\
13\end{array}$ & F & $\begin{array}{c}\text { males. } \\
6 .\end{array}$ & ;....." & $\begin{array}{l}\text { Persons. } \\
19\end{array}$ \\
\hline 1875 & ... & ... & $\ldots$ & 16 & ....... & 5 & ...... & 21 \\
\hline 1876 & ... & $\ldots$ & $\ldots$ & 20 & ...... & 6 & ....... & 26 \\
\hline 1877 & ... & ... & $\ldots$ & 12 & ...... & 7 & ....... & 19 \\
\hline 1878 & ... & $\ldots$ & $\ldots$ & 13 & ...... & 6 & ....... & 19 \\
\hline 1879 & ... & $\ldots$ & $\ldots$ & 14 & • & 9 & .. & 23 \\
\hline 1880 & $\ldots$ & $\ldots$ & $\ldots$ & 17 & ...... & 9 & & 26 \\
\hline 1881 & ... & ... & $\ldots$ & 24 & ....... & 7 & ...... & 31 \\
\hline 1882 & ... & $\ldots$ & $\ldots$ & 27 & ...... & 10 & ...... & 37 \\
\hline 1883 & ... & $\cdots$ & $\ldots$ & 24 & ...... & 9 & ....... & 33 \\
\hline & & he & $\left.\begin{array}{l}10 \\
\ldots\end{array}\right\}$ & 180 & & 74 & & $254^{\prime \prime}$ \\
\hline
\end{tabular}

Liverpool, May 5th, 1885. GEO. E. WALKER, F.R.C.S.

\section{A DANGER FROM DRAIN VENTILATION.}

To the Editor of The LANCET.

SIn,-Not long ago, when attending a young lady with ulcerated throat, I heard of a family several members of which were for a long time ill with troublesome ulceration of the throat, the cause of which was for a time a mystery. It was at last found out that the ventilating pipes in connexion with the drains of an adjoining building were not carried up above the roof, the result of this arrangement being that sewer gas found its way into the dwelling of the patients by the upper windows. Now, when so much is being done in the way of drain ventilation, it becomes obviously a most important matter for the ventilating shafts to be carried well above all windows that may be in proximity. In the heavy air of a town it is especially important to let the gas escape at an altitude where there is some air current to blow it away.

Welbeck-street, W., June, 1885.

1 am, Sir, yours obediently,

\section{COCAINISATION OF THE BLADDER. To the Editor of THF LANCET.}

SIR, - I see that you refer in your issue of May 30th to an interesting case of litholapaxy, rendered painless by the injection of cocaine into the bladder, the operation being performed by Professor Bruns. Permit me to point out that the complete anæsthesia induced in this case is not obtainable in all. From the startling success of the first cocaine litholapaxy, performed at St. Peter's Hospital for Stone soon after the introduction of the drug, it was expected that cocaine would partially supersede the ordinary anæsthetic in operations upon the vesico-urethral tract. Subsequent experience, however, has clearly shown that it cannot always be relied upon to produce anæsthesia. I would quote two cases illustrating the extremes.

A. S - , aged nineteen, had suffered from difficulty in micturition for twelve years. Passed blood at onset of symptoms; none since. Had been treated for the last three years for gleet. Applied at the out-patient department at St. Peter's in January; stone detected. Eight grammes of a 4 per cent. solution of cocaine were injected into the bladder, and the stone crushed and evacuated without pain. The stone weighed fifteen grains.

D. G-, aged forty-five, had suffered for two year from stone, classical symptoms being present. Sixteen grammes of a 7 per cent. solution were injected. On attempting to crush the stone much pain was experienced, and the operation had to be completed under ether. The stone weighed eighty-five grains.

Upon what does this resistance to the action of the drug depend? Deficient knowledge of its properties, probable sources of error in its application, great chances of adulteration, and all combine to prevent a correct answer being giren. A careful consideration of unequivocal cases of cocaine resistance will prove of great value, for I do not doubt that a thorough microscopical examination of the pathological condition of such will afford a clue to some of the many, and at present inexplicable, neuroses of mucous membranes. I am, Sir, yours truly,

E. HuRRY FeNWICK, F.R.C.S.

George-street, Hanover-square, W., June, 1885.

\section{LUNACY AMENDMENT ACT.} To the Editor of THE LANCET.

SIn,-The workhouse medical oflicers appear to me not to have awakened to the serious manner in which their interests are threatened by the above Bill. In the first place, they will, in country places, be subjected to great inconvenience by the disqualification of officiating clergymen, as a magistrate is not to be found always within a reasonable distance, and, when found, his superior intelligence is not always to be reckoned upon. It appears to me that this clause is instigated by the judicial mind, which is unable to free itself from the old-fashioned idea that lunacy is in some sort a crime, and should be dealt with by a justice.

By the amendments of May 13th it is provided that "an alleged lunatic may be received into a workhouse and detained for not more than forty-eight hours." This ought to be three days, for obvious reasons: very many cases cannot be decided upon at one interview; often friends should be communicated with, facts ascertained and verified; and when a Sunday intervenes the relieving officer and magistrate cannot be communicated with and distances traversed all within the short period of forty-eight hours.

Clause 10 , subsections 4 and 5 , provides that "no person shall be detained in a workhouse for more than fourteen days without an order under the hand of a justice; and this order must be made on the application of a reliering officer supported by a medical certificate in Form 6 under the hand of a duly qualified medical practitioner, not being an officer of the workhouse, and by a certificate under the hand of the medical officer of the workhouse in the Form 8 of the schedule." This is followed by a penal clause imposing a fine not exceeding $£ 10$ on the medical officer for every day, or part of a day, during which he omits to perform the preceding duties.

Now, as some medical officers have entertained doubts as to the purport of the above - and I have read the Act through with a solicitor, a barrister, and a stipendiary magistrate,I give its meaning and effect. A medical officer will not have the power to detain any lunatic in the workhouse without sending the case before a magistrate and another medical man with a certificate from himself. This being imposed upon him as part of his duty as workhouse medical officer, he will not be able to claim any payment for it; this is confirmed by a clause in the amendments of May 13th, which runs thus: "The guardians of the union to which the workhouse belongs shall pay such reasonable remuneratlon as they think fit to the medical practitioner who, not being an officer of the workhouse, examines a person under this section." Thus, it is beyond all doubt that the workhouse medical officer, having had the trouble and care of the case, is defrauded of a fee and placed in a subordinate insulting position. It will also be harsh and injurious to the unfortunate lunatic, as the medical officer will not be able, as he is now, to grant permission to the friends to take the patient out for a few days' holiday, and readmit the case without further trouble; but after it is decided upon by the magistrate and the outside doctor, he or she will be rirtually a perpetual prisoner in the workhouse.

Every one of the 17,330 cases now in the workhouses 